\title{
Analysis on Strategies to Promote Quality of Employment of Yunnan Minority Nationality College Students*
}

\section{Li Guang}

NO.16 YuanZheng Road, BaoShan University Education School, LongYang Distinct,

BaoShan City, YunNan Provence, China 678000

Email: 781216468@qq.com

\begin{abstract}
Employment problem of Yunnan minority nationality college students is closely watched by the whole society and involves the interests of many parties. It has important influence on the country, society, enterprises, schools, families and individuals. Preliminary study found that indexes for measuring quality of employment of minority college students included employment rate, working conditions, salary and welfare, etc. Based on this, measures to promote quality of employment of Yunnan minority nationality college students are put forward, including improving employment rate of minority college graduates, raising professional matching rate in graduates' jobs, creating good working conditions, meeting the students' basic needs for salary and welfare, improving social security for students' work, encouraging students to start their own businesses, stimulating students' job satisfaction, making good job preparation, etc.
\end{abstract}

Keywords: Minority Nationality College Students, Employment Quality, Human Resources, Employment Psychology, Career

\section{Introduction}

Since 1970, many foreign organizations have come up with different concepts about quality of employment, such as "Quality of Work Life" by the US Vocational Training and Development Committee, "Decent Work" by the ILO, "Quality of Job and Employment" by the European Foundation, employment quality index by Canadian Imperial Bank, and "work quality" by the European Commission. In 2005, the European Commission unified quality of employment evaluation index system, which includes 10 dimensions and corresponding measurement indexes of quality of work, lifelong learning and career development, health and work safety, etc. Domestic scholars Yang Qinghe et al. established 3 primary indexes (working conditions (64\%), labor relations (17\%) and labor security (19\%)) and 13 secondary indexes for quality of employment evaluation index system. Also, Ke Yu, Zhang Kangsi, Zhang Yaoxiang et al. built corresponding quality of employment evaluation index system from different angles.

Yunnan Province border areas are typical "old revolutionary base areas, frontier areas, poverty-stricken areas and areas inhabited by national minorities". Quality of employment of minority nationality college students reflects efforts made by employment system parties to a large extent. The way to improve quality of employment is to reform and renovate the whole process management of education and teaching. The fundamental purpose is to strengthen development and management of human resources of high-level and highly educated talents in minority areas, and to provide support for national stability, regional prosperity and personal value realization.

\section{The status quo of quality of employment of Yunnan minority nationality college students}

Quality of employment of Yunnan minority nationality college students is far lower than the overall domestic level. The main reasons include poor working conditions, lack of psychological preparation for employment, lack of social security and low job satisfaction, so there is expectation gap between the employer and job seekers and it is difficult to reach a tacit understanding. The fundamental reason is that policy orientation, social needs, employer orientation, school education management lack organic links with personal career planning development, degree of mutual cooperation is low, and it is difficult to construct harmonious labor relations, smooth communication mechanism and win-win situation in which each takes what he needs. At the

\footnotetext{
* Author introduction: Li Guang, BaoShan University Education School lecturer. research direction: human resources development and management, higher education management.

Project: The achievements of "Empirical research on the quality of employment evaluation index of Yunnan minority nationality college students" (project number:2016QN04) of the employment and entrepreneurship university graduates in the education department of yunnan province.
} 
same time, structural reform of the supply side leads to constant changes in industrial structure, labor structure and employment environment, which brings serious challenges to quality of employment of minority nationality college graduates. Ultimately, "employment difficulty" evolves into a difficult problem for the government, hidden danger for social development, weakness of employers and obstacles to individual development.

\section{Recommendations to improve quality of employment of Yunnan minority nationality college students}

\subsection{Improve employment rate of minority college graduates}

Employment rate is the primary indicator of quality of employment. Seen from employment statistics in Yunnan Province, the employment rate has steadily increased. Due to differences in major, employment rate calculated at different times has obvious differences, but end-of-year employment rate has satisfactory results, indicating that there is a certain improvement in quality of employment of minority graduates. In employment rate statistics process, we should continue to strengthen employment statistics, conduct in-depth investigation and analysis in accordance with relevant information to ensure that the data is true and effective. At the same time, data with changes should be updated in a timely manner to ensure timeliness of statistical data.

Affected by major, geographical and employment preferences factors, etc. employment rate can reflect needs of the society. Colleges and universities should adjust disciplinary structure in a timely manner based on social needs, seek improvement from number of enrollment, curriculum and teaching methods to improve employment rate of graduates. In addition, colleges and universities should take the initiative to explore new ways to improve quality of employment, seek mechanism innovation, implement differentiated guidance, and provide classified guidance to students with different employment expectations to effectively improve employment rate.

\subsection{Improve professional matching rate of graduates' jobs}

Professional disagreement has become a common phenomenon, which not only reflects the inconsistency between college professional settings and market demand, but also reflects drawbacks of China's education system. Schools should adjust disciplinary structure based on social needs, adhere to employment-orientation, and meet the development needs of individual students. Colleges and universities should strive to give full play to the integration advantages of university-industry cooperation, explore "cooperative education, cooperative employment", carry out "order-oriented" training, and strive to cultivate practical minority students. At the same time, colleges and universities should comprehensively improve overall quality of students, guide students in career planning so that they understand their career development direction, to truly promote student growth.

\subsection{Create good working conditions}

Unit type determines working conditions to a large extent. Seen from the employment statistics information, employer types include private enterprises, state-owned enterprises, education, institutions, state organs, special posts, three supports and one assistance volunteers, western volunteers, flexible employment and independent entrepreneurship. For different units, nature of employment, working hours, working environment, job stability, job adaptation and work atmosphere are different. With the development of the non - public economy, private enterprises have gradually expanded, minority college graduates have increasing employment channels, and different individuals have increasing differences in demand for working conditions. Employers should pay attention to students' job hobbies and concerns, and strive to achieve docking with working conditions, to effectively improve matching between the two sides.

\subsection{Meet the students' basic needs for salary and welfare}

With the development of economy, overall salary and welfare level of the whole society has been improved year by year. Salary and welfare factors are still the key factors influencing employment of minority college graduates, which reflects students' quality of employment. In general, high salary and welfare means high quality of employment. The level of salary and welfare provided by organizations reflects level of competitiveness in the labor market. To obtain the human resources needed, organizations should first consider whether their salary and welfare meet students' basic needs.

\subsection{Improve social security of student work}

Social security conditions mean social security provided by the employer to employees based on labor law, which cover old-age insurance, medical insurance, unemployment insurance, work injury insurance, maternity insurance and housing provident fund, plus other benefits provided by the unit. Perfect safeguards provided by organizations to graduates concern their ability to withstand work risk, which is the basis for ensuring high quality employment and an important factor in reducing separation rate. 


\subsection{Encourage students to start their own businesses}

Under the call of "mass entrepreneurship and innovation", wave of "public entrepreneurship, grassroots entrepreneurship" rises across the country, and independent entrepreneurship has become an important way for minority college graduates to improve quality of employment. Government work report clearly put forward that mass entrepreneurship and innovation can "both expand employment, increase the income of residents, and promote social vertical mobility and fairness and justice", stressing that "people can better achieve spiritual pursuit and one's own value in the process of creating wealth." Construction of entrepreneurial platform and provision of entrepreneurial help mechanism can help minority university graduates better start their own businesses and give full play to their value and talent, which has a significant guiding role in improving quality of employment.

\subsection{Stimulate students' job satisfaction}

Job satisfaction can reflect working status and development prospects of students, which is a subjective indicator to measure quality of employment. Working conditions, leadership behavior, management measures, interpersonal relationships have a significant impact on job satisfaction, employers and students should enter into labor agreement based on objective, fair and trustworthy principle, and improve the above conditions as far as possible to promote bilateral cooperation. In order to stimulate job satisfaction of minority graduates, employers can provide challenging work, fair pay, good working environment, harmonious interpersonal relationships and matching work platforms.

\subsection{Make full preparation for employment}

Whether graduates can find a matching job depends on their competencies such as skills, quality and motivation. Specifically, they should have an objective understanding of self, and clear career goals. Colleges and universities should guide students to understand the self, develop a scientific career planning, master basic job search skills; students should prepare knowledge, ability and skills in school; consolidate professional skills and comprehensive quality and master multi-dimensional skills and knowledge according to the needs of society and employers. Students should establish correct view of career and employment; maintain peace of mind, timely learn to adjust employment mentality. Also, students should integrate meeting social needs with realizing value of life, develop positive, optimistic, self-strengthening employment psychology, and deal with employment difficulties properly.

\section{Conclusions}

Employment and employment quality of minority college students concern the overall situation of harmony and stability, as well as construction and development of well-off society. Individual students should serve as the basis, pay attention to social needs, and conform to national policy, while colleges and universities should offer specific employment guidance, so that complete employment quality working system can be formed. Through mutual cross cooperation among government, society, enterprises, schools and individuals, situation of resource sharing, complementary advantages, mutual benefit can be achieved to jointly improve quality of employment of minority college graduates. At the same time, we should pay attention to evaluation \& feedback of quality of employment, gradually build a three-level vertical evaluation mechanism of higher evaluation, school self-evaluation, graduate evaluation and four-level horizontal assessment mechanism of industrial enterprises, employing units, inter-school, social intermediary organizations, form multi-party assessment pattern, establish error \& deviation correction mechanism for continuous improvement and perfection of weak links, and solidly and effectively improve quality of employment of Yunnan minority nationality college students.

\section{References}

[1] Yang Xianmei, Li Jina. Study on Evaluation of College Graduates' Employment Quality Based on AHP and BP Neural Network [J]. Journal of The Chinese Society of Education .2015.11.

[2] Zhu Sihong, Shan Zhengyi. Strategies to improve quality of employment of higher vocational college graduates [J]. Journal of Ningbo Institute of Education, 2016.3.

[3] Shi Yunsheng, Tian Biqin. Survey on employment quality of college graduates [J]. Co-Operative economy \& Science, 2014.1.

[4] Zhou Hua. Survey on employment quality of minority students of higher vocational colleges [J]. Guizhou Ethnic Studies, 2013.5. 